\title{
Review on the Evaluation Frameworks of Non-academic Impact of Scientific Research
}

\author{
Xuehui Jin, Guiquan Xi, Lin Cong \\ Beijing Institute of Science and Technology Information, No.140 Xizhimenwai Street, Xicheng District, Beijing, China
}

\begin{abstract}
Assessing the academic impact of scientific research had made great achievement, but nonacademic impact had been neglected for long time in China. This paper used documentary research to analyze representative evaluation frameworks and then summarize the corresponding relation between different evaluation frameworks and their guiding theories. This paper believed that people need to analyze the different conditions when using them because of different frameworks with different background. At last this paper advocated the non-academic impact of research should be paid attention to knowledge consumers from the wider social class, not only to decision makers. It was also well worth studying the timing of non-academic impact of research.
\end{abstract}

\section{Introduction}

The research findings can be recognized and used that was the only way to realize the value of scientific research. They can be recognized by academic peers which we called peer review (academic impact), or by the public by the way of social applications which we called non-academic impact. The former had been concerned, while the latter had been neglected for a long time.

What did non-academic impact mean? In short it meant all kinds of impact beyond the academic circle, including political, cultural, economic, environmental and social impact, and so on. There were many similar names such as "societal impact of research", "usefulness of research", "public values", "knowledge transfer", "societal relevance", and so on. We defined it as social contributions beyond academic contributions. It was social utility in essence. That was to say that research played a role in promoting or hindering social development. From that aspect, we thought that its impact may be good or bad. From the literature and practice cases we can see that the non-academic impact of scientific research sometimes referring to the policy impact--the transformation of knowledge into policy.

\section{The typical evaluation framework of non-academic impact and its application}

It was most difficult to measure and evaluate nonacademic impact of scientific research. There have been many models and frameworks to try to solve this problem, but so far there had been no absolute answer.

\footnotetext{
Corresponding author: author@e-mail.org
}

We would introduce and analyze several representative evaluation frameworks below.

\subsection{The payback framework}

U.S. non-profit research group Rand Corporation used payback framework to evaluate political and social impact of FoW (the Future of Work Programme) being funded by ESRC (Economic and Social Research Council). This framework divided the impact of scientific research into five parts: knowledge contribution, impact on future research, policy impact, social and economic impact. And also divided nonacademic impact of scientific research into five parts: policy impact, potential policy impact, practice impact, potential practice impact and the impact on researchers' career promotion. It thought knowledge playing a role in changing potential users' inner cognition was sometimes soon and sometimes slow. Therefore it was very important to identify its time span.

Table 1. Impact classification of science research

\begin{tabular}{|c|c|}
\hline \multirow{4}{*}{ Impact of } & Knowledge contribution \\
\cline { 2 - 2 } scientific research & Impact on future research \\
\cline { 2 - 2 } & Policy impact \\
\cline { 2 - 2 } & Social impact \\
\hline \multirow{4}{*}{$\begin{array}{c}\text { Non-academic } \\
\text { impact of } \\
\text { scientific research }\end{array}$} & Policy impact \\
\cline { 2 - 2 } & Potential policy impact \\
\cline { 2 - 2 } & Practice impact \\
\cline { 2 - 2 } & The impact on researchers' career \\
& promotion \\
\hline
\end{tabular}

Through questionnaire, interview and case analysis, this report drew some valuable conclusions: 
- Policy environment played a decisive role in nonacademic impact.

- The media played a supporting role in nonacademic impact.

- Lack of application record mechanism led to track the non-academic impact more difficult.

- In general, research projects rarely caused radical policy change, usually playing a role in waving of public opinion or leading policy fine-tuning.

Payback framework used the forward-tracking method to evaluate the non-academic impact, and had some limitations:

- It was not convincing to evaluate the overall impact of a plan which included many projects by sampling. Because different projects had different ways to play their role in policy and society, there was a unified and same pattern.

- The framework was a linear evaluation model which focused on outcome evaluation, but the process of research impact was much more complex than it in reality.

- It ignored the environment of research, the evaluation conclusions may be effective in some condition, but in another condition was not.

This framework provided a set of practical and operable indicators for evaluating non-academic impact of scientific research, and was widely used in social science.

\subsection{ESRC framework}

This framework was used to track and assess the nonacademic impact of an AIDS project funded by ESRC. It divided assessment elements into three types: research outputs, diffusion channels and impacts.

Table 2. Three types of the elements in ESRC framework

\begin{tabular}{|c|c|}
\hline $\begin{array}{c}\text { Research } \\
\text { outputs }\end{array}$ & $\begin{array}{c}\text { The codified knowledge being used to } \\
\text { record new skills, new methodologies and } \\
\text { new tools, or conceptual descriptions. }\end{array}$ \\
\hline $\begin{array}{c}\text { Diffusion } \\
\text { channels }\end{array}$ & $\begin{array}{c}\text { The channels by which research was } \\
\text { transferred, such as the media, publication, } \\
\text { networks. }\end{array}$ \\
\hline Impacts & $\begin{array}{c}\text { The ways in which non-academic users } \\
\text { used the research outputs, for example } \\
\text { helping users directly or indirectly solve } \\
\text { the production or life problems, change } \\
\text { the users' awareness and judgment. }\end{array}$ \\
\hline
\end{tabular}

This framework was not linear. It took into account the sequential and simultaneous impacts.

\subsection{Approach to measure the impacts of medical research on decision making}

Lavis et al. examined and analyzed eight cases from Ontario and Saskatchewan in Canada (four health research programs in each province). They found the key informants for each program according to clues provided by program managers and users. They asked these informants to describe whether health research played a role in decision making, and what were the processes and conditions. They built a framework of impact assessment by investigation. This framework mainly evaluated the impact of health research on decision making, not the societal changes. Users were identified and the impact measures were divided into three categories:

- Producer (researcher)-push measures

- User (decision maker, the public, patients, clinician, manager, development officer, and so on)pull measures

- Exchange measures, joint effort by both groups to solve the problem.

Within each of these categories can be grouped according to the process, the intermediate outputs and the full outputs.

Lavis et al. advocated the receptor mechanism to drive the communication between producers and users. The decision makers need to establish accountability mechanisms for the practical application of projects, not only focus on the citation. If people only evaluated the immediate and direct impacts and ignored the potential and indirect impacts, the important value of research may be covered up, missing the best opportunity to use research results.

\subsection{CHASS framework}

This framework was developed by Council for the Humanities, Arts \& Social Science (CHASS) for evaluating research projects funded by CHASS, including the quality, impact and final goals. It consisted of four parts:

Part one: sources of funding, mainly referring to the project sponsor, including private and public funding.

Part two: research process. These problems need to be answered as followed: who it was done by? where it was done?

Part three: the outputs of the research, including the publication channels such as the media, the media or the internet.

Part four: the outcomes of research, mainly societal benefits.

CHASS was developed on the basis of Payback Model. It took two-communities theory as a guide and thought that there was a significant difference in the values, the preference of knowledge dissemination between researchers and decision makers. So the evaluation was done according to the source of the project, the research process and the outputs, which directly or indirectly reflected and decided the communication between the two groups. 


\subsection{IDRC framework}

Lindquist believed that people should have a realistic anticipation about the potential impact of the projects funded by International Development Research Center (IDRC). The public institutions supported the policy consultation not only for the direct and obvious impacts but also for promoting the negotiation and dialogue among related parties and sharing some good ideas. In fact most ideas and even innovations were not directly transferred into policies, and a few may even be eliminated for various kinds of reasons. Therefore it need classify and identify all kinds of impacts. Lindquist divided the policy influence into nine types (see Table3).

Table 3. Three types of policy impacts of research in IDRC framework

\begin{tabular}{|c|l|}
\hline \multirow{2}{*}{$\begin{array}{c}\text { Expanding } \\
\text { policy } \\
\text { capacities }\end{array}$} & $\begin{array}{l}\text { Increasing the knowledge/data } \\
\text { storage of actors }\end{array}$ \\
\cline { 2 - 2 } & $\begin{array}{l}\text { Opening up ideas of decision } \\
\text { makers }\end{array}$ \\
\cline { 2 - 2 } &
\end{tabular}

\begin{tabular}{|c|l|}
\cline { 2 - 2 } & $\begin{array}{l}\text { Promoting the ideological } \\
\text { communication }\end{array}$ \\
\cline { 2 - 3 } Broadening & $\begin{array}{l}\text { Training research and analysis } \\
\text { talents }\end{array}$ \\
\hline \multirow{4}{*}{$\begin{array}{c}\text { policy } \\
\text { horizons }\end{array}$} & $\begin{array}{l}\text { Building a communication } \\
\text { network }\end{array}$ \\
\cline { 2 - 2 } & $\begin{array}{l}\text { Proposing new ideas and new } \\
\text { concepts that put on the political } \\
\text { debate }\end{array}$ \\
\cline { 2 - 2 } & $\begin{array}{l}\text { Helping researchers and } \\
\text { participants forming a better } \\
\text { understanding of the problem }\end{array}$ \\
\cline { 2 - 2 } & $\begin{array}{l}\text { Promoting calm dialogue among } \\
\text { policy makers }\end{array}$ \\
\hline \multirow{2}{*}{$\begin{array}{c}\text { Affecting } \\
\text { policy } \\
\text { regimes }\end{array}$} & $\begin{array}{l}\text { Causing the revision of the } \\
\text { existing policy and planning }\end{array}$ \\
\cline { 2 - 2 } & $\begin{array}{l}\text { Reversing the existing planning or } \\
\text { policy and redesigning it }\end{array}$ \\
\hline
\end{tabular}

IDRC framework summarized the problems of evaluation into three sets: the policy problems, the objectives and expectations and key outputs and events (see Fig. 1).

\begin{tabular}{|c|c|c|}
\hline $\begin{array}{l}\text { Describe the policy } \\
\text { problem }\end{array}$ & $\begin{array}{l}\text { The objectives and } \\
\text { expectations }\end{array}$ & $\begin{array}{l}\text { Key outputs and events } \\
\text { and influence during he } \\
\text { process of the project }\end{array}$ \\
\hline $\begin{array}{l}\text { - What was the problem, gap } \\
\text { and opportunity? } \\
\text { - Who was responsible for } \\
\text { - dealing with these problems? } \\
\text { - What were their analytical } \\
\text { capacities for these problems? } \\
\text { - What were the dominant? } \\
\text { - What were key events or } \\
\text { decisive moment shaping the } \\
\text { policy situation, such as the } \\
\text { changes of internal } \\
\text { government or the emergence } \\
\text { of new crisis. } \\
\text { - Whether decision-making } \\
\text { mechanism was routine or } \\
\text { progressive, basic or } \\
\text { temporary? }\end{array}$ & $\begin{array}{l}\text { - What was the motivation of } \\
\text { the project, and it was for } \\
\text { capacity building, for } \\
\text { delivering ideas or for } \\
\text { pursuing for policy impact? } \\
\text { - Who did it try to influence? } \\
\text { - Did it depend on policy } \\
\text { entrepreneur? Were they } \\
\text { government officials? } \\
\text { - Did the project foresee the } \\
\text { potential difficulties in } \\
\text { advance? } \\
\text { - Did it need the government to } \\
\text { open policy window for it? }\end{array}$ & $\begin{array}{l}\text { - Was the project going well? } \\
\text { - What were key outputs of it? } \\
\text { - What were key events and } \\
\text { important external events } \\
\text { relating to it? } \\
\text { - Did policy entrepreneur play } \\
\text { an anticipated or exceeding } \\
\text { role? Was there new policy } \\
\text { entrepreneur appeared? } \\
\text { - Were there unexpected events } \\
\text { or opportunities? } \\
\text { - Had the policy impact been } \\
\text { reached? Was there an } \\
\text { - alternative policy impact? } \\
\text { What did the project in the } \\
\text { future? }\end{array}$ \\
\hline
\end{tabular}

Fig. 1. IDRC strategic evaluation framework

\subsection{The survey of knowledge transfer in $\mathrm{CSCl}$ research groups}

INGENIO (CSCI-UPV, the Polytechnic University of Valencia) launched a survey and further evaluated knowledge transfer in CSCI research groups. They 
summarized the ways of knowledge transfer in social science including the media (TV, radio, newspaper and magazines). Close collaboration with company, country's public sector, foundation, NGO was another way to promote knowledge transfer. The mechanism of knowledge transfer was summarized five types (see Table4).

Table 4. Ways and mechanism of knowledge transfer in social science

\begin{tabular}{|c|l|}
\hline $\begin{array}{c}\text { Ways of } \\
\text { knowledge } \\
\text { transfer in } \\
\text { social science }\end{array}$ & $\begin{array}{l}\text { The media (TV, radio, newspaper } \\
\text { and magazines) }\end{array}$ \\
\cline { 2 - 2 } & $\begin{array}{l}\text { Collaboration with company, } \\
\text { country's public sector, } \\
\text { foundation, NGO }\end{array}$ \\
\hline \multirow{4}{*}{$\begin{array}{c}\text { Knowledge } \\
\text { transfer } \\
\text { mechanism in } \\
\text { social science }\end{array}$} & Technical consultation \\
\cline { 2 - 2 } & Cooperation contract \\
\cline { 2 - 2 } & Research result exchange among \\
\cline { 2 - 2 } & Training \\
\cline { 2 - 2 } & Intellectual property \\
\hline
\end{tabular}

It was found that, unlike natural science, intellectual property was not a main tool to transfer knowledge for social science. Informal exchange and cooperation was a more common than it.

The survey paid special attention to the potential users and beneficiaries. But the results showed the communication between researchers and potential users was disappointing, and some researchers even didn't know who their users were. The main reason may not lie in users (such as the differences of their education and occupation), but the research was not sufficiently disseminated by CSCI. Academic papers were most important indicator of career promotion in CSCI, but knowledge transfer was realized mainly through some commercial activities such as R\&D contracts, patents, licenses and derivatives, which were appropriate criteria in natural science but not appropriate in social science.

\section{The guiding theories of evaluation frameworks}

\subsection{The guiding theories}

Many theories and models were put forth when scholars analyzed knowledge transfer and nonacademic impact of research. On the basis of knowledge flow between researchers and users, this paper summarize a logical system for it (see Table5).

Table 5. The model system of research utilization

\begin{tabular}{|c|c|c|c|}
\hline $\begin{array}{c}\text { First } \\
\text { categories }\end{array}$ & $\begin{array}{c}\text { Second } \\
\text { categories }\end{array}$ & Third categories & Presenters \\
\hline
\end{tabular}

\begin{tabular}{|c|c|c|c|}
\hline \multirow[t]{14}{*}{$\begin{array}{l}\text { Linear } \\
\text { model }\end{array}$} & \multirow{5}{*}{$\begin{array}{l}\text { Research- } \\
\text { driven } \\
\text { models }\end{array}$} & $\begin{array}{l}\text { Knowledge- } \\
\text { driven model }\end{array}$ & Weiss \\
\hline & & $\begin{array}{c}\text { Engeering } \\
\text { model }\end{array}$ & $\begin{array}{c}\text { B. } \\
\text { Wittrock }\end{array}$ \\
\hline & & $\begin{array}{c}\text { Expert politics } \\
\text { model }\end{array}$ & $\begin{array}{c}\text { B. } \\
\text { Wittrock } \\
\end{array}$ \\
\hline & & $\begin{array}{l}\text { The embedded } \\
\text { research model }\end{array}$ & Walter \\
\hline & & $\begin{array}{c}\text { The two- } \\
\text { communities } \\
\text { theory }\end{array}$ & Caplan \\
\hline & \multirow{9}{*}{$\begin{array}{l}\text { Demand- } \\
\text { pull } \\
\text { models }\end{array}$} & $\begin{array}{l}\text { Policy-driven } \\
\text { model }\end{array}$ & $\begin{array}{c}\text { B. } \\
\text { Wittrock }\end{array}$ \\
\hline & & $\begin{array}{c}\text { Problem-driven } \\
\text { model }\end{array}$ & Weiss \\
\hline & & Political model & Weiss \\
\hline & & Tactical model & Weiss \\
\hline & & $\begin{array}{c}\text { Instrumental } \\
\text { model }\end{array}$ & Lavis \\
\hline & & $\begin{array}{c}\text { Conceptual } \\
\text { model }\end{array}$ & Lavis \\
\hline & & $\begin{array}{l}\text { Evidence-based } \\
\text { decision model }\end{array}$ & Rand \\
\hline & & $\begin{array}{c}\text { The two- } \\
\text { communities } \\
\text { theory }\end{array}$ & Caplan \\
\hline & & $\begin{array}{c}\text { The ladder of } \\
\text { research } \\
\text { utilization }\end{array}$ & $\begin{array}{c}\text { Knott, } \\
\text { Wildavsky }\end{array}$ \\
\hline \multirow[t]{4}{*}{$\begin{array}{l}\text { Non- } \\
\text { linear } \\
\text { model }\end{array}$} & \multirow[t]{4}{*}{$\begin{array}{l}\text { Interactiv } \\
\text { e model }\end{array}$} & $\begin{array}{c}\text { The } \\
\text { organizational } \\
\text { excellence } \\
\text { model }\end{array}$ & Davies \\
\hline & & $\begin{array}{l}\text { Collaborative } \\
\text { approach/linkag } \\
\text { e and exchange }\end{array}$ & $\begin{array}{l}\text { Kogan, } \\
\text { Henkel }\end{array}$ \\
\hline & & $\begin{array}{c}\text { Enlightenment } \\
\text { model }\end{array}$ & Weiss \\
\hline & & $\begin{array}{c}\text { The symbolic } \\
\text { model }\end{array}$ & Lavis \\
\hline
\end{tabular}

The frameworks in the second chapter were summarized by research practice on basis of these models and theories. Table6 summarized the guiding theories of these frameworks.

Table6. Evaluation frameworks and their guiding theories

\begin{tabular}{|c|c|c|}
\hline Frameworks & $\begin{array}{c}\text { The guiding } \\
\text { theories }\end{array}$ & $\begin{array}{c}\text { Areas of } \\
\text { application }\end{array}$ \\
\hline $\begin{array}{c}\text { Payback } \\
\text { framework }\end{array}$ & $\begin{array}{c}\text { The Two- } \\
\text { communities } \\
\text { theory }\end{array}$ & $\begin{array}{c}\text { Economics/socia } \\
\text { l science }\end{array}$ \\
\hline $\begin{array}{c}\text { CHASS } \\
\text { framework }\end{array}$ & $\begin{array}{c}\text { The Two- } \\
\text { communities } \\
\text { theory }\end{array}$ & $\begin{array}{c}\text { Humanities and } \\
\text { social science }\end{array}$ \\
\hline $\begin{array}{c}\text { ESRC } \\
\text { framework }\end{array}$ & $\begin{array}{c}\text { Enlightenment } \\
\text { model }\end{array}$ & $\begin{array}{c}\text { Economics/socia } \\
\text { l science }\end{array}$ \\
\hline $\begin{array}{c}\text { Approach to } \\
\text { measure the }\end{array}$ & $\begin{array}{c}\text { Collaborative } \\
\text { approach/linkag }\end{array}$ & Health \\
\hline
\end{tabular}




\begin{tabular}{|c|c|c|}
\hline $\begin{array}{l}\text { impacts of } \\
\text { medical } \\
\text { research on } \\
\text { decision } \\
\text { making }\end{array}$ & e and exchange & \\
\hline $\begin{array}{c}\text { IDRC } \\
\text { framework }\end{array}$ & $\begin{array}{l}\text { Enlightenment } \\
\text { model }\end{array}$ & All areas \\
\hline $\begin{array}{c}\text { CSCI } \\
\text { knowledge } \\
\text { transfer } \\
\text { survey }\end{array}$ & $\begin{array}{c}\text { Knowledge } \\
\text { transfer theory }\end{array}$ & $\begin{array}{l}\text { Humanities and } \\
\text { social science }\end{array}$ \\
\hline
\end{tabular}

\subsection{Characteristics analysis}

Through the review of evaluation framework, we found that:

(1) The research of non-academic impact was not a new direction without any progress, and it had achieved a lot in the aspects of theories and frameworks.

(2) An evaluation framework was often designed for a specific organization or even for a project to satisfy users' demands in line with the objective conditions at that time. Therefore there was no uniform framework to be generally applicable to all problems of non-academic impact. When we assessed non-academic impacts of research we should design a case-by-case framework according to its concrete realities and conditions in order to the objectivity and accuracy of results.

(3)These frameworks abstracted the "influence" into "process". These frameworks evaluated the nonimpact of research mainly based on the project process and time sequence.

\section{Conclusions}

The non-academic impact of research was paid more and more attention with social development. These frameworks broke through narrow understanding about "impact". The non-impact of research included not only the policy impact but also social, economic, cultural and environmental impact. Through a comprehensive study, we believed there were following aspects worthed thinking:

(1) The non-academic impact of research would be a long-term and top topic for a long time. The topic on non-academic impact of research remained largely ignored until a so-called New Social Compact carrying over to social science. With the emergence of these concepts such as new public administration, new public management, decision consultation, think tank and so on, and with the change of assessment of publicly funded research from academic value evaluation to practical value evaluation, the non- academic impact of research would be a long-term topic.

(2) The studies on non-academic impact often paid more attention to producers rather than users. How can users discover these projects and get new information and absorb new knowledge from them, and what was the result? Those questions need we thoroughly ponder and research. The "policy narrative" theory of Roe was just a start.

(3) The studies on non-academic impact paid more attention to the transfer between knowledge and policy, and paid more attention to policymakers' demand. That showed research was a strongly utilitarian. The users of the publicly funded projects were not only policymakers, but also people of all walks of life who can also spread knowledge and had an influence on policy through various channels. So the future research should also pay attention to the different users' demand and the evaluation criteria should be more pluralistic.

(4) The research of time law on non-academic impact. Garfield believed that paper cited peak time often was two years. Enlightened by Garfield's cited peak time theory and Bernal's half-life of literature, We also asked whether non-academic impact of research was time limited. We thought there can be no doubt about the answer, because research was carried out in a certain environment, and nonacademic impact must be environmentally sensitive. The social value of some basic research may have emerged three or five years later. It was important for researchers to have the patience to wait for an appropriate occasion. However, the non-academic impact of the research for hot spots of society was more time-limited. It was well worth studying the timing of non-academic impact.

\section{References}

1. Carol H. Weiss. 1979. The many meanings of research utilization[J]. Public Administration Review, P 426-431.

2. Patrica Thomas. 1985. The Aims and Outcomes of Social Policy Research[M]. Landon: Croom Helm, P 114.

3. Carol. H. Weiss. 1991. Policy Research as Advocacy: Pro and Con[J]. Knowledge and Policy, P 37-55.

4. Edward Nason, Lisa Klautzer, Jennifer Rubin, et al. 2007. Policy and Practice Impacts of Research Funded by the Economic and Social Research Council: a Case Study of the Future of Work 
Programme, Supporting Data[R]. California: RNAD Corporation, P 1-137.

5. M. Buxton, S. Hanney. 1996. How can Payback from Health Services Research be Assessed[J]. Journal of Health Service Research and Policy, P $35-43$.

6. Hum Davies, Sandra Nutley, Isabel Walter. 2005. Assessing the Impact of Social Science Research: Conceptual, Methodological and Practice Issues[EB/OL].[2017-06-23].

https://www.researchgate.net/profile/Huw_Davies5/ publication/237525328_Assessing_the_impact_of_s ocial_science_research_conceptual_methodological _and_practical_issues/links/56013a2c08aec948c4fa 9f24/Assessing-the-impact-of-social-scienceresearch-conceptual-methodological-and-practicalissues.pdf.

7. John N. Lavis, Suzanne E. Ross, Jeremiah E. Hurley, et al. 2002. Examining the Role of Health Services Research in Public Policymaking[J]. The Milbank Quarterly, P 125-154.

8. CHASS. 2009. Measures of Quality and Impact of Publicly Funded Research in the Humanities, Arts and Social Sciences[EB/OL].[2017-06-23]. http: / /www.chass.org.au /papers /pdf /PAP20051101JP.pdf.

9. Caplan, N. 1979. The Two-communities Theory and Knowledge utilization[J]. American Behavioral Scientist, P 459-470.

10. Isabel Walter, Sandra Nutley, Janie Percy-Smith, et al. 2004. Improving the Use of Research in Social Care Practice[R]. London: the Social Care Institute for Excellence(SCIE), P 1-147.

11. Caplan, N. 1979. The Two-communities Theory and Knowledge utilization[J]. American Behavioral Scientist, P 459-470. 